\title{
Abundance dynamics of mites (Acari) in the peatland of 'Linie' Nature Reserve, with particular reference to the Gamasida
}

\author{
SŁAWOMIR KACZMAREK, KATARZYNA FALEŃCZYK-KOZIRÓG \\ and TOMASZ MARQUARDT \\ Kazimierz Wielki University, Institute of Environmental Biology, Department of Zoology, \\ Ossolińskich Av. 12, PL-85-094 Bydgoszcz, Poland \\ Corresponding author: Sławomir Kaczmarek, slawkacz@ukw.edu.pl
}

(Received on 16 January 2008; Accepted on 26 October 2011)

\begin{abstract}
The research was conducted in 'Linie' Nature Reserve within the Lower Vistula Valley Landscape Park in central Poland. We analysed the annual abundance dynamics of soil mites as well as changes in gamasid community parameters (abundance, age structure, species diversity). Density changes among the juvenile Gamasida greatly influenced the annual abundance dynamics of mites belonging to that order. Alternations in the abundance dynamics of Platyseius italicus and Zercon zelawaiensis were connected to the appearance of males as well as the density increase in juvenile specimens of those species.
\end{abstract}

Keywords: Acari, Gamasida, abundance dynamics, ecology, peatland reserve, Zercon zelawaiensis, Platyseius italicus

\section{INTRODUCTION}

Abundance dynamics of a population depends on environmental conditions as well as on intra-population parameters (BEGON \& MORTIMER 1989). The main factors that directly influence the seasonal changes in density are climatic conditions, population parameters, and the food base (CZARNECKI 1978; SENICZAK et al. 1994; BŁosZYK 1999; Griegel 1999, 2000; Skoracka et al. 2001; Materna 2003; SøviK et al. 2003; Zolda 2005; Chachas \& SeniczaK 2006; Chor et al. 2006). In many cases it is impossible to tell the difference between density fluctuations caused by reproduction or mortality and those connected to changes in environmental factors. Abundance changes in a population during the year might also result from periodic aggregation of individuals in places of optimum humidity or temperature or in order to reproduce (GóRNY 1975).

The aims of this study were: (1) to analyse changes in general and group abundance of soil mites in 'Linie' Nature Reserve; (2) to determine gamasid community parameters (abundance, age structure, species diversity) within the studied peatland; and (3) to broaden the knowledge of the factors that shape the abundance dynamics of the mites. 


\section{MATERIAL AND METHODS}

The research was carried out within 'Linie' Nature Reserve. The reserve is located in central Poland, within the boundaries of the Lower Vistula Valley Landscape Park (PAJĄKOWSKI 1998). The reserve was created in 1956 to protect dwarf birch (Betula nana L. 1753), which is a post-glacial relic (CEYNowA-GieŁdon 1971). The vegetation of the study area was classified as the association Sphagno apiculati-Caricetum rostratae Osvald $1923 \mathrm{em}$. Steffen 1931. The herb layer covered 70\% of the area, while the moss layer covered $100 \%$. The most numerous species of that area were: Carex rostrata Stokes, Vaccinium oxycoccos L., Sphagnum fallax (Klinggr.), Betula nana L., Eriophorum vaginatum L., and E. angustifolium Honck.

The material for research was collected between 23 October 2003 and 25 September 2004, in monthly intervals and 40 replications each time. Overall, 480 soil samples $\left(50 \mathrm{~cm}^{3}\right.$ each) were collected. The samples were taken from 2 artificially set sublevels $(0-4 \mathrm{~cm}$ and $4-8 \mathrm{~cm})$. As a result of extraction for 6 days, we collected 24649 mites, including 22101 of the Oribatida and 449 of the Gamasida. The collected mites were then preserved in $70 \%$ ethyl alcohol and finally mounted in Hoyer's medium. The Gamasida, both mature and immature specimens, were identified to the species or genus level.

At the time of soil sampling, measurements of soil temperature were made (Table 1). The results showed that the year in which the research was carried out was different from the long-term mean, as relatively high temperatures were recorded in winter.

The community analysis was based on indices of abundance $\left(A\right.$, in $10^{3}$ ind. $\left./ \mathrm{m}^{2}\right)$, number of species $(S)$, and Shannon index of species diversity $\left(H^{\prime}\right)$. Moreover, the age structure of selected families and species of the Gamasida was analysed.

Table 1. Soil temperature in 'Linie' Nature Reserve during the study period (at the depth of $5 \mathrm{~cm}$, mean values of 5 measurements made during sampling)

\begin{tabular}{ccccccccccccccc}
\hline Year & \multicolumn{1}{c}{2003} & \multicolumn{1}{c}{2004} \\
\hline Month & Oct & Nov & Dec & Jan & Feb & Mar & Apr & May & Jun & Jul & Aug & Sep \\
\hline $\begin{array}{c}\text { Temperature } \\
\left.\text { (in }{ }^{\circ} \mathrm{C}\right)\end{array}$ & 9.30 & 7.07 & 1.70 & -1.07 & 0.52 & 3.95 & 7.64 & 10.03 & 11.74 & 13.37 & 16.27 & 15.03 \\
\hline
\end{tabular}

\section{RESULTS}

Mites were the most numerous in winter (maximum in January, about 84850 ind. $/ \mathrm{m}^{2}$ ). Starting in February, their density decreased, to a minimum in May (16 020 ind. $/ \mathrm{m}^{2}$ ) and then it increased again in late summer (Table 2). The highest density of 


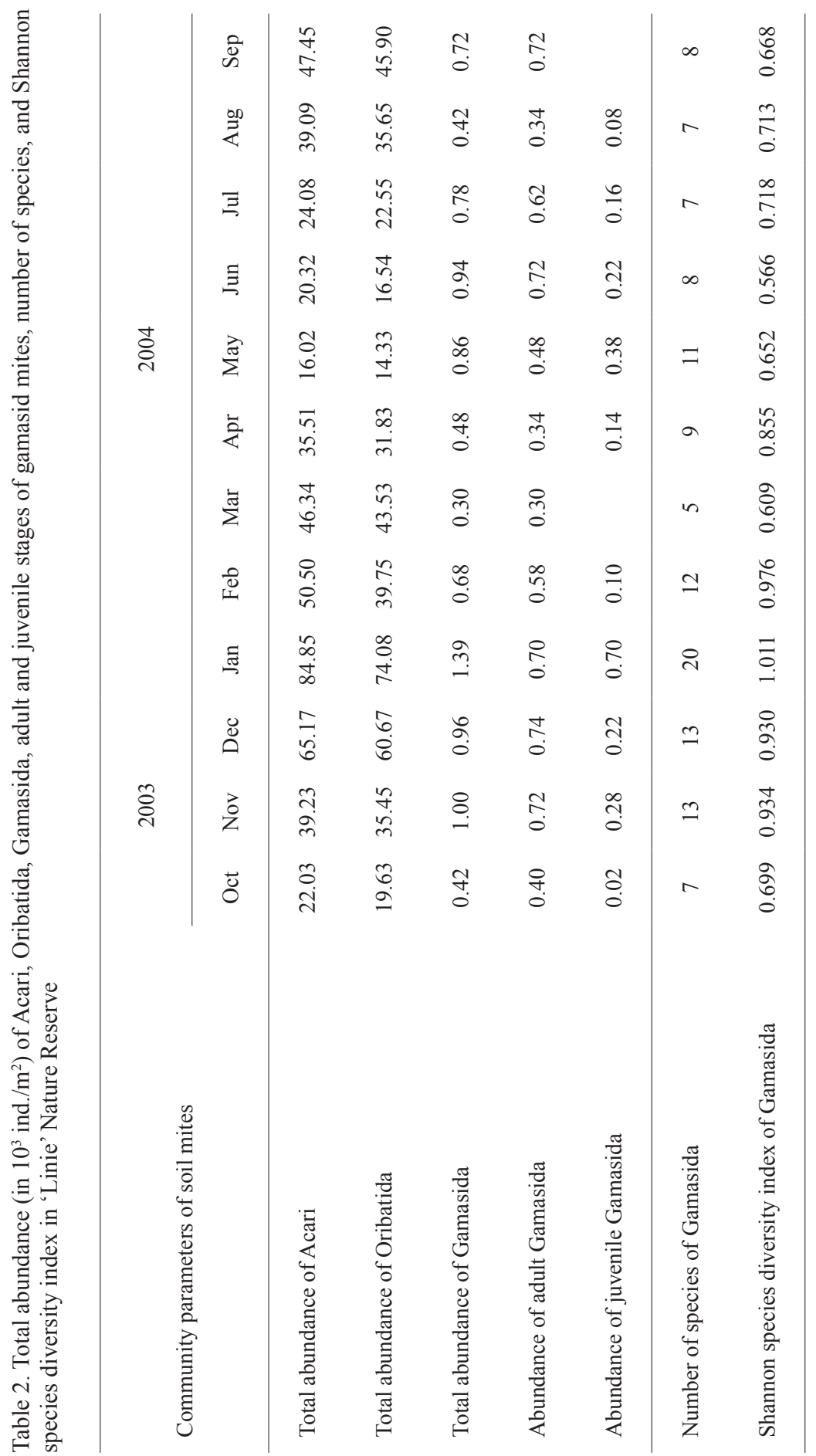


the Oribatida was also recorded in January (74 080 ind. $/ \mathrm{m}^{2}$ ), but it was only slightly lower in December, and another abundance increase was observed in late summer (July-September). In the Gamasida, there were also 2 density peaks. The first one was in winter (maximum in January 1390 ind. $/ \mathrm{m}^{2}$ ), followed by a density decrease of approximately $80 \%$ (minimum in March about 300 ind $/ \mathrm{m}^{2}$ ). The second abundance peak was in late spring and summer (maximum in June 940 ind. $/ \mathrm{m}^{2}$ ). It is worth pointing out that the abundance of Oribatida at that time was the lowest (Table 2).

Altogether, 28 gamasid species were recorded (Table 2). The highest number of gamasid species (20) was documented in January, followed by a decrease (minimum: 5 species in March) and then another increase (10 species in May). Similar changes were noted with respect to the Shannon index, whose highest value also occurred in winter (maximum in January, $H^{\prime}=1.011$ ), and the lowest in June $\left(H^{\prime}=0.566\right.$ ) (Table 2).

Between autumn and winter, an increase in the share of juvenile specimens in the gamasid community was recorded (their highest abundance was noted in January, about 700 ind.$/ \mathrm{m}^{2}$ ). Afterwards, their abundance decreased (no juvenile forms in March) and then another increase (maximum: 380 ind. $/ \mathrm{m}^{2}$ in May) (Table 2).

Among the Gamasida, most species belonged to the families Ascidae (between $33.33 \%$ and $74.47 \%$ of gamasid species) and Zerconidae (between $4.76 \%$ and $33.33 \%)$.

The highest density of the family Ascidae was recorded in June (about $700 \mathrm{ind} . / \mathrm{m}^{2}$ ), when it was 5-fold higher than the minimum (April and August). Juvenile forms of the Ascidae were present in January and between April and July. Their abundance was the highest in May, when they constituted nearly $40 \%$ of the total abundance of mites of this family (Table 3). Among the Ascidae, the highest abundance was reached by Platyseius italicus, whose density was the highest in June (600 ind $\left./ \mathrm{m}^{2}\right)$. Juvenile forms of that species were present exclusively between April and July and they constituted between $12.5 \%$ and $40 \%$ of the population. Males in May and June constituted approximately $50 \%$ of adult specimens, but were not observed in other months. Their appearance was noted simultaneously with the appearance of juvenile forms.

The highest density of the Zerconidae was recorded in late autumn and early winter (maximum in December, 320 ind. $/ \mathrm{m}^{2}$ ). The same period was also characterised by an abundance increase among juvenile forms (in November they constituted $60 \%$ of the total number of mites of this family) (Table 3). Zercon zelawaiensis was the most abundant in the family. The November and December increase in abundance of Z. zelawaiensis coincided with the density increase among its juvenile specimens, which were recorded during nearly the whole period of research. A density peak of males of that species was noted simultaneously (approximately $60 \%$ of them were adults).

\section{DISCUSSION}

The main factor that enables a mite population abundance increase is humidity, so in Europe two abundance peaks are usually observed: in spring and in autumn (REEVES 1967). They largely result from the appearance of juvenile specimens, 


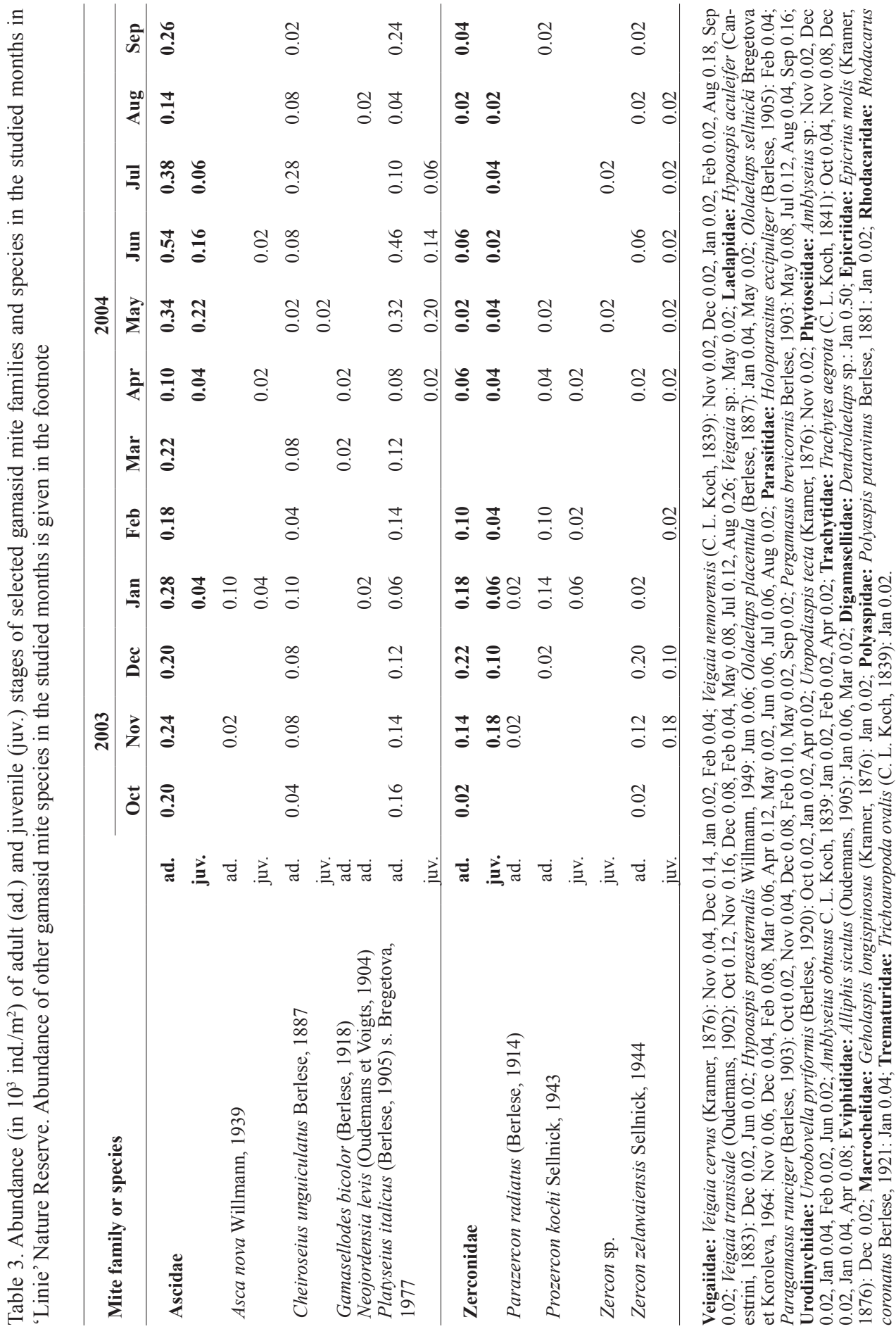


whereas in the summer the proportions change to the advantage of adult specimens (NiedBAŁA 1980). However, except for the macroclimatic conditions, the dynamics of mite communities also depends on the local factors, e.g. the microclimate or habitat type. That can be proved by the appearance of the abundance peaks among mites in different periods of the growing season, depending on the microenvironment (ScheneKer 1986; Seniczak et al. 1988, 1993, 1994; BŁoszyk 1999; Griegel 2000; Skoracka et al. 2001; Materna 2003; Chachaj \& Seniczak 2006). The winter increase in mite abundance in the studied area could have been connected to the relatively mild winter as well as the biology of the species, which shaped the abundance level of all mites at that time. Similar changes in the abundance of mites in wintertime were also recorded in patches of moderately moist coniferous forest, where the highest abundance was recorded in February (SENICZAK et al. 1993).

Since the Oribatida account for the largest part of the mite community (in the studied peatland they constituted approximately $90 \%$ of the total abundance), it is the abundance dynamics of that group that influences the changes in density of all mites. That relationship is confirmed in the research on the soil acarofauna of various habitats (SENICZAK et al. 1988, 1993, 1994).

The abundance dynamics of the Gamasida within the studied reserve was clearly shaped by the density changes of juvenile specimens - their abundance peak coincided with the high abundance of the Gamasida. A similar dependence of the abundance dynamics of the population on the density changes of juvenile forms was recorded with both the Gamasida and the Oribatida in a mid-field forest community with the dominant sessile oak Quercus robur (SENICZAK et al. 1994). The observed abundance increase in the predatory Gamasida (late spring), followed by their decline and an increase in the saprophagous Oribatida (summer) were probably associated with the predator-prey relationship, which had already been documented (SENICZAK et al. 1994).

The relatively small number of recorded species, together with the low level of species diversity $\left(H^{\prime}\right)$ of gamasid communities within the studied peatland, probably result from the fact that peatlands are ecosystems at early stages of succession and are poorly diversified with respect to microenvironments. Similar results concerning peatland mites had been already reported (KACZMAREK et al. 2006a, 2006b).

The presented results indicate that species of the family Ascidae procreate in the early part of the growing season. This is evidenced by the recorded increase in the density of juvenile specimens in late spring and early summer. It is also confirmed by previous results about the biology of this mite family (SKORACKA et al. 2001). The most abundant species of the family Ascidae is Platyseius italicus. It appeared in very large numbers in late spring and early summer, which was influenced by the appearance of juvenile forms. Simultaneously, males of that species occurred only in that period (they constituted approximately $50 \%$ of adult specimens). Between autumn and early spring (March) there were no records of juvenile forms, which indicated that Platyseius italicus overwinters as adults. These results suggest that the abundance dynamics of Platyseius italicus is clearly connected to its biology.

In the family Zerconidae, density increased in late autumn and early winter and was connected to the increased abundance of juvenile specimens in that period. However, juvenile zerconids were present in the community practically the whole 
year long. The abundance dynamics of the most abundant species of that family, i.e. Zercon zelawaiensis, was also connected to the density changes among juvenile forms. Abundance changes in the population of $Z$. zelawaiensis during the year indicate that the development of its population is especially intense in late autumn and early winter.

\section{CONCLUSIONS}

1. The Oribatida are a group of mites that influence abundance changes of the whole acarofauna. A high abundance of that order and of all mites was recorded in winter and spring.

2. Abundance dynamics of juvenile Gamasida greatly influenced the abundance dynamics of this order. Abundance peaks of mites of that group coincided with the abundance peaks of juvenile forms.

3. Abundance dynamics of Platyseius italicus was connected to its biology. The highest abundance of the whole population was recorded in May and June, and it coincided with the density peak among juvenile specimens and the appearance of males.

4. Abundance dynamics of Zercon zelawaiensis was also connected to its biology. Its total population peaked in late autumn and early winter, which coincided with the increased density of juvenile specimens and the appearance of a higher number of males.

\section{REFERENCES}

Begon M., Mortimer M. 1989. Ekologia populacji. Studium porównawcze zwierząt i roślin [Ecology of the population. A comparative study of animals and plants]. PWRiL, Warszawa (in Polish).

BŁoszyK J. 1999. Geograficzne i ekologiczne zróżnicowanie zgrupowań roztoczy z kohorty Uropodina (Acari, Mesostigmata) w Polsce [Geographical and ecological variability of mites of the cohort Uropodina (Acari: Mesostigmata) in Poland]. Wyd. Kontekst, Poznań (in Polish).

Ceynowa-Gietdon M. 1971. Osobliwości florystyczne i rezerwaty Ziemi Chełmińskiej [Floral peculiarities and natura reserves of Chelmno Land]. Przewodnik Florystyczny, Państwowe Wydawnictwo Naukowe, Torun (in Polish).

Chachaj B., Seniczak S. 2006. Seasonal dynamics of the density of Oribatida (Acari) in a lowland meadow and pastures. Biological Lett. 43: 153-156.

Choi W. I., Moorhead D. L., Neher D. A., Ryoo M. I. 2006. A modeling study of soil temperature and moisture effects on population dynamics of Paronychiurus kimi (Collembola: Onychiuridae). Biol. Fert. Soils 43: 69-75.

CZARnecki A. 1978. Produktywność skoczogonków w grądzie rezerwatu "Las Piwnicki” [Productivity of springtail communities in oak-hornbeam reserve "Las Piwnicki"]. Acta UNC Biol. 44: 75-91 (in Polish).

GóRnY M. 1975. Zooekologia gleb leśnych [Zooecology of forest soils]. PWRiL, Warszawa (in Polish).

Griegel A. 1999. Räumliche Verteilung und jahreszeitliche Dynamik von Kleinarthropoden (Collembola, Gamasida) in den Auen des Unteren Odertals. In: Limnologiae aktuell (DoHLE W., Bornkamm R., Weigmann G., Eds.), vol. 9, pp. 211-227, E. Schweizerbart Science Publishers, Stuttgart. 
Griegel A. 2000. Auswirkungen von Überflutungen auf die Zönosen der Collembolen und der Gamasiden (Insecta: Collembola, Acari: Gamasida) in der Flussaue des Unteren Odertals. Verlag im Internet disseration.de, Berlin.

Kaczmarek S., Marquardt T., Marcysiak K. 2006a. Preliminary research on communities of soil gamasid mites (Acari) in three different pine forests in the 'Bagno Stawek' Reserve (Tuchola Forest, N Poland). In: Advances in Polish Acarology (Gabryś G., Ignatowicz S., Eds.), pp. 137-138, SGGW, Warszawa.

Kaczmarek S., Marquardt T., Marcysiak K., Badzińska M. 2006b. Mites (Acari) of peatlands in the 'Wielkie Torfowisko Batorowskie' Reserve and the 'Bagno Stawek' Reserve, with particular reference to the Gamasida. In: Advances in Polish Acarology (Gabryś G., Ignatowicz S., Eds.), pp. 168-173, SGGW, Warszawa.

Materna J. 2003. Structure and seasonal dynamics of oribatid communities (Acari: Oribatida) inhabiting moss covers on granite boulders in a mountain spruce forest. In: Proceedings of the $7^{\text {th }}$ Central European Workshop on Soil Zoology (Tajovský K., Schlaghamerský J., PižL V., Eds.), April 14-16, 2003, České Budějovice, Czech Republic, pp. 91-94, Tisk Josef Posekaný, České Budějovice.

Niedbata W. 1980. Mechowce - roztocze ekosystemów lądowych [Oribatida - mites of terrestrial ecosystems]. Państwowe Wydawnictwo Naukowe, Warszawa (in Polish).

PająKowski J. 1998. Przyroda Ziemi Świeckiej [Nature of Świecie Land]. Wydaw. TPDW, Świecie (in Polish).

Reeves R. M. 1967. Seasonal distribution of some forest soil Oribatei. In: Proceedings of the $2^{\text {nd }}$ International Congress of Acarology (Evans G.O. Ed.), Bonington (England), 19th-25th July, 1967, pp. 23-30, Akadémiai Kiadó, Budapest, Hungary.

SCHENEKER R. 1986. Population dynamics of oribatid mites (Acari: Oribatei) in forest soil ecosystem. Pedobiologia 29: 239-246.

SenicZak S., Kaczmarek S., RatyŃska H. 1994. Dynamika liczebności roztoczy (Acari) w 1992r. w zadrzewieniu śródpolnym zdominowanym przez dąb bezszypułkowy w okolicach Turwi [The dynamics of mites (Acari) abundance in 1992 in an oak spinney in an agricultural landscape near Turew]. Zesz. Nauk. ATR Bydgoszcz, Zootech., 26: 133-145 (in Polish).

Seniczak S., Klimek A., Górniak G., Kaczmarek S. 1988. Dynamika liczebności roztoczy (Acarida) w płatach słonorośli w rejonie oddziaływania Janikowskich Zakładów Sodowych w 1986r. [Seasonal variation of abundance of mites (Acarida) in halophyte patches in the region of Janikowo Soda Factory]. Zesz. Nauk. ATR Bydgoszcz, Zootech., 16: 119-131 (in Polish).

Seniczak S., Klimek A., Górniak G., Peter E. 1993. Dynamika liczebności roztoczy (Acari) w płatach boru świeżego z mchem w zasięgu oddziaływania emisji zanieczyszczeń Zakładów Azotowych we Włocławku [Seasonal variations of mites (Acari) abundance in moss patches of Scots pine forest in the region polluted by a nitrogen factory at Włocławek]. Zesz. Nauk. ATR Bydgoszcz, Zootech., 23: 99-119 (in Polish).

Skoracka A., Skoracki M., BŁoszyk J., Stachowiak P. 2001. The seasonal abundance of Mesostigmata (Acari) in compost. In: Proceedings of the $6^{\text {th }}$ Central European Workshop on Soil Zoology (TajovskÝ K., Balík V., PıžL V., Eds.), April 23-25, 2001, České Budějovice, Czech Republic, pp. 163-167, Tisk Josef Posekaný, České Budějovice.

Søvik G., Leinaas H. P., Ims R. A., Solnøy T. 2003. Population dynamics and life history of the oribatid mite Ameronothrus lineatus (Acari, Oribatida) on the high arctic archipelago of Svalbard. Pedobiologia 47: 257-271.

Zolda P. 2005. Seasonal dynamics of soil nematode community structure in semi-natural grasslands under pasture. In: Proceedings of the $8^{\text {th }}$ Central European Workshop on Soil Zoology (Tajovskí K., Schlaghamerský J., Pižl V., Eds.), April 20-22, 2005, České Budějovice, Czech Republic, pp. 213-215, Tisk Josef Posekaný, České Budějovice. 